JPPIPA, Vol. 3 No. 22018
Jurnal Penelitian Pendidikan IPA
http://journal.unesa.ac.id/index.php/jppipa

\title{
PENGUJIAN VALIDITAS E-LEARNING MENGGUNAKAN PORTAL PEMBELAJARAN MAHASISWA UNTUK MATA KULIAH KONSEP DASAR IPA 1 DI PROGRAM STUDI PGSD UN PGRI KEDIRI
}

Oleh:

Kharisma Eka Putri

UN PGRI Kediri, Indonesia

\begin{abstract}
Abstrak
Penelitian pengujian validitas E-learning menggunakan portal pembelajaran mahasiswa untuk mata kuliah konsep dasar IPA 1 di program studi PGSD UN PGRI Kediri bertujuan untuk mengetahui kelayakan $E$ learning yang dikembangkan. Kelayakan pengembangan E-learning didasarkan pada hasil validasi ahli. Metode penelitian yang digunakan adalah penelitian pengembangan (development research) dengan model pengembangan Rowntree yang terdiri dari tiga tahap yaitu: 1) tahap perencanaan; 2) tahap pengembangan; dan 3) tahap evaluasi. Pada tahap evaluasi menggunakan tahap self evaluation dan expert review. Teknik pengumpulan data menggunakan lembar validasi. Data dari lembar validasi akan dianalisis secara deskriptif kualitatif. Hasil penelitian menunjukkan pada tahap expert review nilai presentase rata-rata total dari validator sebesar 3,42 dengan kategori sangat baik atau valid. Berdasarkan hasil penelitian dapat disimpulkan bahwa pengujian validitas E-learning menggunakan portal pembelajaran mahasiswa untuk mata kuliah konsep dasar IPA 1 di program studi PGSD UN PGRI Kediri layak digunakan.
\end{abstract}

Kata Kunci: Penelitian pengembangan, Portal pembelajaran, Konsep dasar IPA 1

\begin{abstract}
E-learning validity testing research used students' learning portals for the subject of Basic Science 1 in PGRI Kediri at PGSD UN study program aimed to determine the feasibility of developed E-learning. The feasibility of developing E-learning was based on the results of experts' validation. The research method used was development research with the development of the Rowntree's model which consists of three stages, namely: 1) the planning stage; 2) the development stage; and 3) evaluation phase. The evaluation stage used the stages of self evaluation and expert review. The technique of collecting data used a validation sheet. Data from the validation sheets were analyzed qualitatively. The results showed that in the expert review stage the average percentage value of the validator was 3.42 with a very good or valid category. Based on the results of the study, it can be concluded that E-learning validity testing used the students' learning portal for the subject of Basic Science 1 in PGRI Kediri at PGSD UN study program was appropriate to be used.
\end{abstract}

Keywords: Development research, Learning portal, Basic concepts of Science 1

(C) 2018 Universitas Negeri Surabaya

Alamat Korespondensi:

UN PGRI Kediri, Indonesia

E-mail: kharismaputri@unpkediri.ac.id

\section{PENDAHULUAN}

Pesatnya perkembangan teknologi dan informasi pada saat ini sangat pesat. Perkembangan tersebut juga diiringi dengan semakin cepatnya perkembangan ilmu pengetahuan dan teknologi (IPTEK), terutama pada teknologi komputer. Sangatlah banyak produk dan manfaat yang dapat diperoleh dari berbagai perkembangan tersebut. Salah satunya
p-ISSN: 2527-7537

e-ISSN: 2549-2209 adalah dalam dunia pendidikan. Di dunia pendidikan teknologi komputer sering digunakan sebagai salah satu media untuk pembelajaran. Dari beberapa produk teknologi yang dihasilkan komputer yang bisa digunakan diantaranya yang sering sekali digunakan adalah Microsoft power point. Produk yang lainnya adalah adobe flash, $e$ book, dan masih banyak lagi.

Portal pembelajaran mahasiswa adalah merupakan pengembangaan teknologi komputer 
yang berbentuk sebuah pintu masuk ke dalam sistem pembelajaran yang berbasis web. Portal pembelajaran ini merupakan pengembangan dari sistem virtual lab yang hanya bisa diakses lokal dalam satu laboratorium saja. Sedangkan portal pembelajaran ini dapat diakses melalui jaringan internet atau on-line. Kelebihan inilah yang dapat mempermudah mahasiswa dalam memperoleh dan memahami materi, mengerjakan soal atau tugas tanpa dibatasi tempat, ruang dan waktu. Sehingga dapat mengoptimalkan pembelajaran dan akhirnya tujuan pembelajaran yang diharapkan dapat tercapai secara maksimal

Komponen learning management system (LMS) yang diperlukan dalam sistem portal pembelajaran mahasiswa adalah content management system (CMS). CMS merupakan bahan ajar yang tedapat dalam LMS yang dapat berupa konten berbentuk multimedia interaktif maupun konteks berbentuk teks seperti bahan ajar biasa.Umumnya CMS yang dibangun adalah dalam bentuk web yang berjalan dengan menggunakan web server dan bisa diakses oleh pesertanya melalui web browser (web client). Cole (2005) menjelaskan fungsi-fungsi umum CMS yaitu memasukan dan menyebarkan materi, forum and chat, kuis, pemberian nilai siswa, serta merekam data siswa secara otomatis

Moodle yang merupakan singkatan dari Modular Object-Oriented Dynamic Learning Environment yang berarti tempat belajar dinamis dengan menggunakan model berorientasi objek adalah salah satu web yang menggunakan sistem CMS. Sesuai dengan namanya Moodle dibuat sebagai tempat belajar yang bisa digunakan secara objektif untuk menilai peserta didik. Fatmawati (2010) menyatakan Moodle yang merupakan aplikasi CMS berbentuk web yang sangat mendukung tercapainya tujuan E-learning. Jadi Moodle adalah sebuah program aplikasi sebagai alternatif media pembelajaran yang berbasis web dan bersifat pedagogi dan menggunakan sistem CMS. Karena Moodle yang mengunakan sistem CMS maka portal pembelajaran mahasiswa bisa menggunakan Moodle sebagai sistem CMS yang digunakan.

Berdasarkan hasil wawancara terhadap mahasiswa Program Studi PGSD yang telah memprogram mata kuliah konsep dasar IPA 1 ditemukan beberapa hambatan yang dialami saat perkuliahan diantaranya: a) dalam memperoleh dan memahami materi dibatasi oleh tempat, ruang dan waktu; b) dalam pemberian tugas dan soal cenderung menyita waktu pembelajaran; dan c) tujuan pembelajaran belum tercapai secara optimal.
Berdasarkan latar belakang di atas peneliti bermaksud untuk melakukan penelitian mengenai "Pengujian validitas E-learning menggunakan portal pembelajaran mahasiswa untuk mata kuliah konsep dasar IPA 1 di program studi PGSD UN PGRI Kediri"'

Rumusan masalah dalam penelitian ini sesuai dengan latar belakang di atas adalah "Bagaimana pengujian validitas E-learning menggunakan portal pembelajaran mahasiswa untuk mata kuliah konsep dasar IPA 1 di program studi PGSD UN PGRI Kediri?

\section{METODE}

Penelitian ini menggunakan metode Development Research dengan model pengembangan Rowntree. Model pengembangan Rowntree terdiri dari 3 tahap, yaitu tahap perencanaan, tahap pengembangan, dan tahap evaluasi (Prawiradilaga, 2008). Penelitian dilaksanakan di prodi PGSD FKIP UN PGRI Kediri. Alur desain penelitian ini dapat dilihat pada gambar berikut:

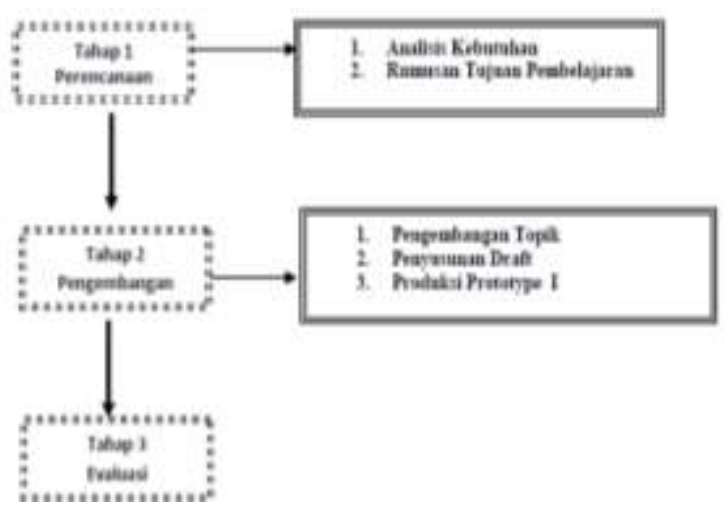

Gambar 1. Alur Desain Penelitian Model Pengembangan Rowntree

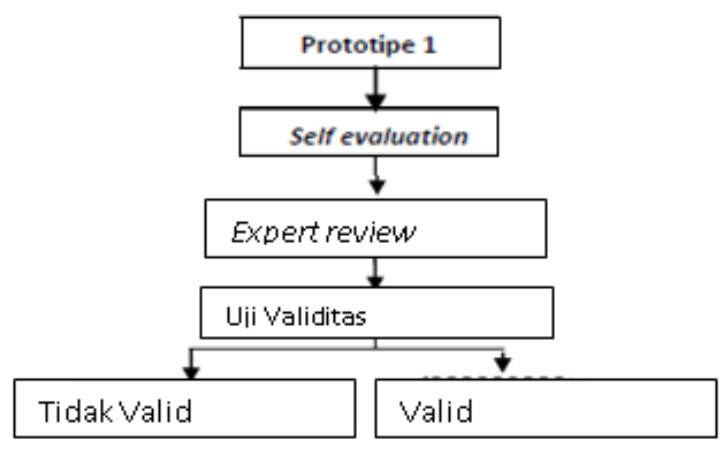

Gambar 2. Alur Desain Penelitian Tahap Evaluasi 
Teknik pengumpulan data yang digunakan adalah proses walktrough atau catatan validator oleh dosen PGSD konsentrasi IPA. Proses ini dilakukan untuk mengetahui gambaran tentang kevalidan produk yang dikembangkan. Validasi yang dilakukan untuk media pembelajaran terdiri dari tiga aspek yaitu aspek materi, aspek media, dan aspek desain pembelajaran. Indikator yang digunakan untuk menilai setiap aspek jumlahnya bergantung pada setiap aspek dan sesuai dengan kebutuhannya.

Analisis validasi ahli menggunakan lembar validasi dengan model check list yang digunakan untuk menilai perangkat pembelajaran yang telah dibuat oleh peneliti apakah telah layak atau tidak. Dengan menggunakan rumus sebagai berikut:

kelayakanperangkatpembelajaran $=\frac{\sum \text { skortotal }}{\sum \text { skorkriteria }}$

\section{$\Sigma$ Skor kriteria $=$ jumlah item $x$ jumlah respon}

Berdasarkan hasil analisis hasil validasi akan diperoleh empat kriteria rata-rata yaitu seperti pada Table 1 berikut:

Tabel 1. Kriteria Skor Validasi

\begin{tabular}{cc}
\hline Skor Rata-rata & Kriteria Skor \\
\hline $1,00-1,75$ & Tidak baik \\
\hline $1,76-2,50$ & Kurang baik \\
\hline $2,51-3,25$ & Baik \\
\hline $3,26-4,00$ & Sangat baik \\
\hline
\end{tabular}

(sumber: Bungin, 2009:333)

\section{HASIL DAN PEMBAHASAN}

Hasil penelitian Pengujian validitas $E$ Learning menggunakan portal pembelajaran mahasiswa untuk mata kuliah konsep dasar IPA 1 di program studi PGSD UN PGRI Kediri ini menggunakan model pengembangan Rowntree. Menurut model Rowntree dalam penelitian pengembangan ini terdiri dari tahap Perencanaan, Pengembangan dan Evaluasi. Pada tahap perencanaan terdiri dari analisis kebutuhan dan rumusan tujuan pembelajaran. Pada tahap pengembangan berupa pengembangan topik, penyusunan draft, dan produksi prototype. Pada tahap evaluasi digunakan model evaluasi menurut Tesmer yaitu self evaluation, expert review dan one to one, small group serta field test. Akan tetapi model evaluasi Tesmer hanya menggunakan dua tahap saja, yaitu tahap self evaluation dan tahap expert review.

\section{Sub Bab 1 Tahap Perencanaan}

Tahap awal dalam penelitian pengembangan ini adalah tahap perencanaan. Pada tahap ini peneliti melakukan analisis kebutuhan dan perumusan tujuan perkuliahan. Dalam analisis kebutuhan peneliti melakukan analisis materi dan silabus sedangkan dalam perumusan tujuan perkuliahan peneliti mengidentifikasi kompetensi dasar yang sesuai dengan silabus mata kuliah Konsep Dasar IPA 1 serta merumuskan tujuan perkuliahan yang hendak dicapai.

Berdasarkan analisis materi dan silabus, maka dapat diindentifikasi beberapa materi yang dapat dikembangkan dalam portal pembelajaran mahasiswa. Materi tersebut terdiri dari klasifikasi tumbuhan, sistem reprodukasi, konsep transportasi, klasifikasi hewan, system sirkulasi dan respirasi hewan, sistem pencernaan dan ekskresi hewan, system syaraf dan panca indra hewan, system gerak pada hewan, konsep ekologi, konsep materi, daur unsur di bumi, konsep perubahan pada mkhluk hidup, dan evolusi. Hasil analisis tujuan pembelajaran dilakukan setelah melakukan analisis kebutuhan. Perumusan tujuan pembelajaran terdiri dari mengidentifikasi kompetensi dasar serta merumuskan materi perkuliahan dan tujuan perkuliahan yang ingin dicapai.

\section{Sub Bab 2 Tahap Pengembangan}

Tahap selanjutnya dari penelitiian pengembangan ini akan dilakukan pengembangan topik, penyusunan draf serta produksi prototype yang akan digunakan untuk proses belajar mengajar. Hasil pada tahap pengembangan topik ini peneliti mengembangkan mata kuliah Konsep Dasar IPA 1 berdasarkan silabus mata kuliah Konsep Dasar IPA 1. Dari 14 kompetensi dasar pada mata kuliah Konsep Dasar IPA 1 semua kompetensi dasar dilaksanakan dengan e-learning.

Pada tahap penyusunan draf dilakukan dengan membuat storyboard atau menulis naskah materimateri yang akan dimasukan dalam e-learning baik berupa teori maupun software yang akan digunakan.

Hasil pada tahap produksi prototype, draf yang telah disusun akan dibuat menjadi sebuah produk yang disebut prototype. Prototype yang dihasilkan 
dalam penelitian ini adalah sebuah e-learning berbantuan portal pembelajaran mahasiswa.

Pada tahap ini, langkah-langkah yang akan dilakukan peneliti adalah sebagai berikut : 1) Membuat LKM, web dan mencari portal pembelajaran mahasiswa yang sesuai dengan kompetensi dasar; 2) Menelaah kembali LKM, portal pembelajaran mahasiswa untuk divalidasi; dan 3) Langkah selanjutnya peneliti melakukan tahap evaluasi dengan cara meminta orang lain untuk menilai atau memvalidasi LKM dan portal pembelajaran mahasiswa yang telah dibuat agar hasilnya layak untuk digunakan.

\section{Sub Bab 3 Tahap Evaluasi}

Tahap Evaluasi merupakan tahapan akhir dalam pengujian validitas e-learning berbantuan portal pembelajaran mahasiswa. Tahapan yang bertujuan untuk mengetahui apakah e-learning berbantuan portal pembelajaran mahasiswa yang sedang dikembangkan telah layak untuk digunakan atau belum. Evaluasi yang digunakan dalam penelitian ini adalah evaluasi formatif dan perbaikan pembelajaran. Perbaikan pembelajaran dilakukan pada setiap tahapan evaluasi formatif. Pada tahap ini peneliti menghasil prototype 1 yang akan dievaluasi, tahap-tahap yang dilakukan adalah self evaluation, dan expert review.

\section{(1) Self Evaluation}

Self evaluation adalah penilaian oleh diri sendiri terhadap prototype instrumen penilaian psikomotorik dalam hal ini berupa rubrik penilaian praktikum dengan cara melakukan pengecekan sendiri tentang konstruk, bahasa dan isi, apakah sudah tepat dan benar. Setelah dirasa cukup dilanjutkan ke tahap evaluasi berikutnya.

(2) Expert review

Prototype 1 yang telah dibuat, kemudian dilakukan validasi berdasarkan validasi materi, validasi media, dan validasi desain pembelajaran dengan melibatkan dosen PGSD konsentrasi IPA sebagai validator materi, melibatkan 2 dosen Teknologi Pendidikan masing-masing sebagai validator media adan validator desain pembelajaran. Pada langkah ini protoype 1 diperlihatkan kepada masing-masing validator, setelah dosen melihat dan menelaah E-learning menggunakan portal pembelajaran mahasiswa, dosen diberikan lembaran validasi untuk menilai kelayakan E-learning menggunakan portal pembelajaran mahasiswa. Adapun hasil rekapitulasi penilaian validasi dapat dilihat pada tabel berikut.

Tabel 2. Rekapitulasi Penilaian Validasi

\begin{tabular}{clcc}
\hline No. & Aspek Validasi & Penilaian $\mathbf{( \% )}$ & Kategori \\
\hline 1 & Materi & 3,50 & Sangat Baik \\
\hline 2 & Media & 3,75 & Sangat Baik \\
\hline 3 & Desain Pembelajaran & 3,00 & Sangat Baik \\
\hline \multicolumn{2}{c}{ Rata-rata } & 3,42 & Sangat Baik (Valid) \\
\hline
\end{tabular}

Validasi yang diberikan dosen memiliki jumlah aspek atau indikator dan peryataan yang berbeda-beda tergantung dari jenis validasi yang diberikan. Skala penilaian yang digunakan peneliti memiliki rentang skor 1 sampai 4 bergantung pada tingkat kesetujuan dosen terhadap E-learning menggunakan portal pembelajaran mahasiswa yang dihasilkan.
Selain memberikan penilaian berdasarkan kriteria yang telah ditetapkan, peneliti juga meminta komentar dan kritik kepada validator sebagai bahan masukan revisi untuk produk pada tahap selanjutnya. Komentar validator yang diberikan bisa dilihat dalam tabel berikut:

Tabel 3. Komentar atau Masukan Validator

\begin{tabular}{cll}
\hline No & Aspek Validasi & Komentar \\
\hline 1. & Materi & $\begin{array}{l}\text { Materi didominasi biologi saja, Mata kuliah Konsep Dasar IPA hendaknya } \\
\text { minimal keterpaduan antara fisika dan biologi yang mempunyai komposisi } \\
\text { yang imbang. }\end{array}$ \\
\hline 2. & Media & Sebaiknya ditambahkan menu untuk berdiskusi secara online. \\
\hline 3. & Desain Pembelajaran & Untuk susunan materi hendaknya diperhatikan kembali. \\
\hline
\end{tabular}

\section{SIMPULAN DAN SARAN}

\section{Simpulan}

Berdasarkan hasil penelitian, tentang Pengujian validitas E-learning menggunakan portal pembelajaran mahasiswa untuk mata kuliah konsep dasar IPA 1 di program studi PGSD UN PGRI Kediri dapat disimpulkan bahwa: $E$ Learning menggunakan portal pembelajaran 
mahasiswa untuk mata kuliah konsep dasar IPA 1 yang di hasilkan telah valid. Hal ini ditunjukan dengan persentase skor para ahli pada aspek materi sebesar 3,50 (sangat baik atau valid), aspek media sebesar 3,75 (sangat baik atau valid), dan aspek desain pembelajaran sebesar 3,00 (sangat baik atau valid).

\section{Saran}

Bagi peneliti berikutnya yang akan mengembangkan E-Learning disarankan untuk mengikuti perkembangan teknologi.

\section{DAFTAR PUSTAKA}

Bungin, B. 2009. Penelitian Kualitatif. Jakarta: Prenada Media Grup

Cole, Jason. Helen Foster. 2005. Using Moodle, USA: O'Reilly.

Prawiradilaga, D. Salma. 2009. Prinsip Desain Pembelajaran (Instructional Design Principles. Jakarta: Kencana Prenada Media Group. 